\title{
Applications of Magnesium Sulfate in Obstetrics and Anesthesia
}

Fabiano Timbó Barbosa, TSA, M.D., Luciano Timbó Barbosa, M.D., Mário Jorge Jucá, M.D., Rafael Martins da Cunha, M.D.

\section{INTRODUCTION}

Magnesium is the second most abundant intracellular cation ${ }^{1,2}$ and the fourth when the extracellular medium is also considered $^{1}$. As a cofactor, it is involved in more than 300 known reactions, such as ${ }^{3}$ : hormone binding to receptors, flow of transmembrane ions, regulation of the adenylate kinase system, muscle contraction, neuronal activity, vasomotor tone, cardiac excitability, release of neurotransmitters, and calcium binding to calcium channels.

In 1906, Haulbold and Meltzer reported sensorial and motor blockades in humans after the intrathecal administration of magnesium; in 1950, magnesium was used in anesthesia, mainly to control seizures in gravidas. Currently, it has several applications in anesthesia, obstetrics, and intensive care $\mathrm{e}^{3-5}$. The objective of this report was to review the physiology, pharmacology, and reduction in plasma levels of magnesium, as well as some of its applications in obstetric and anesthesia.

\section{PHYSIOLOGY AND PHARMACOLOGIC EFFETCS}

Magnesium is an intracellular cation with multiple functions: it participates in energy metabolism, since it is a cofactor in glucose metabolism, and a cofactor of nucleic acid, protein, and fatty acid degradation enzymes ${ }^{5,6}$; it regulates the flow of transmembrane ions ${ }^{5}$; and it mediates the activity of several enzymes ${ }^{5,7}$.

Magnesium is considered a natural physiologic calcium antagonist, having several regulatory mechanisms, such as ${ }^{1-3,8-11}$ : competitive antagonist affecting type $L$ calcium channels, inhibition of the enzyme $\mathrm{Ca}^{2+}$-ATPase, and it is a cofactor for all enzymes that participate in phosphate transferences that use ATP. In high concentrations, it inhibits the enzyme $\mathrm{Na}^{+} / \mathrm{K}^{+}-\mathrm{ATPase}^{5}$.

Magnesium is absorbed in the jejunum and ileum at a proportion of $11 \%$ to $65 \%$ of the ingested amount ${ }^{12}$. The kidney is the main regulator of the levels of magnesium in the body, being capable of eliminating almost $100 \%$ of the filtered magnesium in case of overload 5 .

Medicine has not elucidated completely the mechanism of action of magnesium sulfate used therapeutically ${ }^{13}$. Some of the following propositions have been developed over the years:

a) Inhibition of the release of acetylcholine in the neuromuscular junction ${ }^{9,14}$ leading to muscle relaxation, which has been known since the $1950 s^{3}$. Hypermagnesemia decreases the sensitivity of the motor plate to acetylcholine and the amplitude of terminal end-plate potential ${ }^{9}$.

b) It is an antagonist of NMDA glutamate receptors ${ }^{1,2,5,10,11}$; this receptor is responsible for central sensitization ${ }^{10}$. Bin- 
ding of this receptor has analgesic, anticonvulsant, and sedative properties ${ }^{5}$.

c) It can increase the synthesis of prostacyclins and inhibit angiotensin converting enzyme, leading to vasodilation ${ }^{11}$.

d) It decreases the release of catecholamines after sympathetic stimulus ${ }^{1,5,9,11}$. It has been used in the treatment of pheochromocytoma-related hypertensive episodes during surgeries or outside the surgical environment ${ }^{5}$.

e) In asthma patients, it inhibits the release of histamine and acetylcholine ${ }^{5,16}$, and it potentiates the effects of betaadrenergic agents ${ }^{5}$. It is indicated only in severe cases because it decreases the rate of hospitalizations and the length of stay in the intensive care unit, but it has little beneficial effects in moderate and mild cases ${ }^{16}$.

\section{HYPOMAGNESEMIA}

The human body has 21 to 28 grams of magnesium ${ }^{5}$. It is distributed as follows: $53 \%$ in the bones, $27 \%$ in the muscles, $19 \%$ in the soft tissues, $0.3 \%$ in the red blood cells, and $0.3 \%$ in the plasma 5,6 . Fifty-five per cent of plasma magnesium is ionized and $45 \%$ is bound to plasma proteins or broken into divalent anions, such as phosphate and sulfate $^{6}$. Its plasma concentration ranges from 1.6 to 2.3 mg.dL ${ }^{-1} 5,6$. Since magnesium is an abundant intracellular ion and it is present in the plasma in very low amounts, measuring its plasma levels is not adequate to evaluate real deficiency or overload 5 .

Body magnesium stores are better assessed by measuring the urinary excretion in patients without renal failure ${ }^{5,6}$. Under normal circumstances, a small amount of magnesium is eliminated in the urine ${ }^{6}$. The urinary retention test is performed by collecting 24-hour urine after the intravenous infusion of $6 \mathrm{~g}$ of magnesium sulfate ${ }^{6}$. When more than $70 \%$ of the amount administered is recovered from the urine, the presence of deficiency is unlike ${ }^{5}$, but when less than $50 \%$ is recovered from the urine, body stores are probably deficient ${ }^{6}$.

Hypomagnesemia is seen in $10 \%$ to $20 \%$ of hospitalized internal medicine patients ${ }^{6}$, and $60 \%$ of patients in Intensive Care Units (ICU) $6,7,7 \%$ of admissions for ketoacidosis, $30 \%$ of admissions to the neonatal ICU, and up to $70 \%$ after coronary revascularization in adults ${ }^{5}$. The presence of hypomagnesemia in the surgical ICU has been associated with increased mortality ${ }^{7}$. Clinical signs of hypomagnesemia are non-specific ${ }^{6}$, and they are associated with cardiac arrhythmia $^{8}$, reduction in cardiac index ${ }^{8}$, reduction in neuromuscular excitability $^{7}$, disorientation ${ }^{9}$, seizures ${ }^{9}$, and psychosis $^{9}$. It is the main cause of refractory hypokalemia ${ }^{7}$.

Critical patients have a tendency to develop hypomagnesemia for several reasons: deficient intake, increased losses, and redistribution in the body ${ }^{5}$. The main cause of hypomagnesemia is the use of diuretics and it is seen in $50 \%$ of chronic furosemide users $^{6}$. Other possible causes include ${ }^{5}$ : total parenteral nutrition; pancreatitis; burns; extracorporeal circulation; use of beta-agonists, aminoglycosides, and amphotericin B; diarrhea; acute tubular necrosis; and hypoparathyroidism.
Treatment consists on correcting the underlying cause, whenever possible, and replacement of magnesium ${ }^{5}$. Intestinal absorption of magnesium is erratic and the intravenous route should be preferred for therapeutic use $\mathrm{e}^{5,7}$. Six grams should be administered in 24 hours ${ }^{5,7}$ and, in critical patients, serum levels should be maintained above $2.0 \mathrm{mg} \cdot \mathrm{dL}^{-17}$.

\section{OBSTETRIC APPLICATIONS}

Magnesium sulfate has been used in obstetrics since 1925 for prevention of seizures in eclampsia ${ }^{17,18}$, with the advantage of decreasing peripheral vascular resistance without changing uterine blood flow 5 .

It has been postulated that the anticonvulsant property of magnesium sulfate is due to the blockade of NMDA receptors ${ }^{5,14}$. Considerations on the real effects of magnesium in the treatment of eclampsia-related seizures have been made, since its effects in the neuromuscular junction can mask the real effects of magnesium in the central nervous system ${ }^{19}$. Doses used to depress the activity of the neuromuscular junction have been used in gravidas ${ }^{20}$, and small alterations or even no changes on the electroencephalogram have been reported in some studies with women without eclampsia ${ }^{21}$, with eclampsia ${ }^{22}$, and in animal models ${ }^{23}$. Studies with Doppler flowmetry have demonstrated cerebral vasodilation ${ }^{2,5}$ and reversion of cerebral vasospasm ${ }^{2,15}$ after the administration of magnesium.

The therapeutic serum level for the treatment of seizures ranges from 4.2 to $8.4 \mathrm{mg} . \mathrm{dL}^{-1}$ which can be achieved by the intramuscular administration of $6 \mathrm{~g}$ followed by $2 \mathrm{~g} /$ hour; intravenous administration of 3 to $4 \mathrm{~g}$ (up to $1 \mathrm{~g} / \mathrm{min}$ ) or a combination of both routes ${ }^{19}$. Two administration schedules of magnesium are widely used: Pritchard's and Zuspan's ${ }^{18}$. Pritchard's schedule starts with a 14-gram dose, $4 \mathrm{~g}$ IV and $5 \mathrm{~g}$ in each gluteal region ${ }^{18}$. Maintenance is achieved with $5 \mathrm{~g}$ every 4 hours in the gluteal region ${ }^{18}$. Zuspan's schedule begins with $4 \mathrm{~g} \mathrm{IV}^{18}$, followed by continuous infusion of $1 \mathrm{~g} /$ hour $^{18}$. Elevated plasma levels are associated with adverse effects (Table I); therefore, it is necessary to observe some clinical parameters to guarantee the safety of its use ${ }^{17}$. Those parameters include: diuresis of $25 \mathrm{~mL} . \mathrm{h}^{-1}$, positive patellar reflex, respiratory rate greater than $12 \mathrm{bpm}$, and unchanged vital signs (blood pressure, heart rate, and level of consciousness) ${ }^{17}$. Magnesium decreases by $52 \%$ of the risk of seizures when compared to diazepam, and $67 \%$ when compared to phenytoin ${ }^{24}$. This study increased the use of magnesium from $2 \%$ to $40 \%$ in patients with preeclampsia in the United Kingdom ${ }^{19}$. Benzodiazepines are indicated for the treatment of seizures

Table I - Clinical Manifestations of Hypermagnesemia

\begin{tabular}{ll}
\hline Serum levels in $\mathrm{mg} \cdot \mathrm{dL}^{-1}$ & Symptom \\
\hline $5-9$ & Therapeutic \\
$10-15$ & Areflexia \\
$15-20$ & Respiratory arrest \\
$\geq 25$ & Cardiac arrest \\
\hline
\end{tabular}


only postpartum ${ }^{17}$, in the absence of magnesium sulfate ${ }^{17}$, or when treatment with magnesium sulfate has failed ${ }^{2}$.

Further studies on this area will focus on aquaporin $4^{19}$, a water channel-bound protein found in the final portion of astrocyte axon, whose levels are increased in cerebral edema ${ }^{19}$. Magnetic resonance imaging studies have documented cerebral edema of the white matter of the posterior region of the brain eclampsia patients ${ }^{25}$. This change has also been documented in animal models of eclampsia ${ }^{25}$. The expression of aquaporin 4 is increased in pregnancy ${ }^{26}$, and the use of magnesium sulfate decreases cerebral expression of this protein, which can attenuate cerebral edema in eclampsia patients ${ }^{27}$.

Magnesium has been used as the standard drug for tocolysis during treatment of premature labor, and other drugs have been compared to $\mathrm{it}^{28}$. The mechanism of action has not been completely elucidated, but it seems to be secondary to calcium antagonism by competing for the binding site of this ion ${ }^{28}$. The loading dose for tocolysis ranges from 4 to $6 \mathrm{~g}$ intravenous over 15 to 30 minutes, followed by maintenance with 2 to $6 \mathrm{~g} \mathrm{IV/hour}{ }^{28}$. Several patients treated with magnesium develop minor adverse reactions, such as: feeling hot, scotomata, nausea, vomiting, blurred or double vision, and lethargy 5,28 . Adverse effects can be reverted by the intravenous administration of $1 \mathrm{~g}$ of calcium gluconate ${ }^{5}$.

\section{APPLICATIONS IN ANESTHESIA}

The indications of magnesium sulfate in anesthesia have been increasing over the years to include situations out of the gynecological field ${ }^{5}$. It has analgesic and sedative properties with potential neuro- and cardioprotective effects, although it is not know the mechanisms of those actions ${ }^{5,29}$.

During acute myocardial infarction (AMI), $80 \%$ of the patients develop hypomagnesemia in the first 48 hours, probably secondary to the high serum levels of catecholamines ${ }^{6}$. Magnesium deficiency leads to cell depolarization and promotes tachycardia ${ }^{6}$. Two studies using magnesium in patients with AMI, LIMIT 2 and ISIS 4, showed antagonic mortality results ${ }^{5}$. Only LIMIT 2 showed a reduction in mortality, but magnesium was used before spontaneous or pharmacologic recovery of the occluded vessel ${ }^{5}$. The prophylactic use to prevent hypomagnesemia during extracorporeal circulation is controversial, although reduction in the incidence of ventricular tachycardia and atrial fibrillation has been shown ${ }^{5}$.

Neuronal ischemia leads to the outflow of ATP from the cell and inflow of calcium, which triggers the release of toxic metabolites, culminating with cell death ${ }^{5}$. Blockade of glutamate NMDA receptors inhibits the cellular inflow of calcium and contributes for neuronal protection $3,29-31$. Other probable actions for cerebral protection include: reduction in the presynaptic release of excitatory neurotransmitters ${ }^{32}$, blockade of calcium channels ${ }^{32,33}$, suppression of anoxic depolarization ${ }^{32}$, antioxidant effects ${ }^{31,32}$, and an increase in cerebral blood flow $^{29,30,32,33}$. Besides, cellular energy preservation is also seen, since magnesium is bound to ATP in the cytosol.

Two studies demonstrated antagonic results in patients with cerebral ischemia, IMAGE and FAST-MAG ${ }^{32}$. A $90 \mathrm{mg} \cdot \mathrm{kg}^{-1}$ dose reduced infarction volume after middle cerebral artery embolus by $48 \%$ when administered in the first six hours ${ }^{32}$. It is possible that the doses used in the IMAGE study have not been enough to cause an increase in the concentration of magnesium in cerebral cells ${ }^{15}$.

Magnesium has been used to attenuate the cardiovascular response to tracheal intubation ${ }^{5}$. This effects is, probably, secondary to a reduction in the release of catecholamines after sympathetic stimulation ${ }^{1,3,5,11,34,35}$. A $40 \mathrm{mg} \cdot \mathrm{kg}^{-1}$ dose has shown similar efficacy to that of $10 \mu \mathrm{g} . \mathrm{kg}^{-1}$ of alfentanil as well as greater effectivity than $1.5 \mathrm{mg} \cdot \mathrm{kg}^{-1}$ of lidocaine $\mathrm{e}^{5}$. It is a complementary drug in the treatment of hypertensive episodes during the surgical treatment of pheochromocytoma, since it inhibits the release of catecholamines from the adrenal glands ${ }^{5}$.

Magnesium inhibits the release of acetylcholine in the neuromuscular junction and behaves as a neuromuscular relaxant, potentiating the effects of non-depolarizing neuromuscular blockers ${ }^{5}$. A $40 \mathrm{mg} \cdot \mathrm{kg}^{-1}$ dose of magnesium reduces the $\mathrm{ED}_{50}$ of vecuronium by $25 \%{ }^{5}$. When magnesium is administered before induction, it prevents succinylcholine-induced increase in potassium levels ${ }^{9,36}$. This drug limits muscular fasciculation, but it does not interfere with the time of recovery of succinylcholine ${ }^{36}$.

The analgesic potential of magnesium is partially secondary to the blockade of NMDA receptors, but also to a reduction in the release of catecholamines ${ }^{11}$. The potential to reduce the MAC of volatile anesthetics has been confirmed in laboratorial studies with rat models ${ }^{1,5,37}$, and it can be as high as $60 \%{ }^{1}$. Schutz-Stubner et al. ${ }^{3}$ demonstrated a reduction in the need of remifentanil and fentanyl when one intravenous dose of 50 $\mathrm{mg} . \mathrm{kg}^{-1}$ of magnesium was used in humans. Collateral effects were not observed with this dose ${ }^{3}$.

The postoperative analgesia of magnesium has been analyzed in a systematic review that used qualitative evaluation methods ${ }^{38}$. Fourteen randomized clinical assays with 778 patients, 404 of which received magnesium, were included. Magnesium levulinate, sulfate, and gluconate were tested. Meta analysis could not be carried out due to methodological heterogeneity among the studies secondary to a wide variety of magnesium infusion schedules and among the final treatment objectives of each study ${ }^{38}$. Besides those factors mentioned by the authors of that study, different age groups and surgical procedures of different subspecialties were also included. The author of that review concluded that the studies included in the analysis did not demonstrate convincing evidence that magnesium was beneficial in the treatment of postoperative pain and reduction in analgesic consumption ${ }^{38}$.

\section{FINAL CONSIDERATIONS}

Magnesium sulfate has been used in obstetrics with good results inhibiting of premature labor and in the treatment of eclampsia-related seizures. This drug is potentially analgesic and sedative and it could be used as adjuvant during general anesthesia, reducing the blood pressure response to tracheal intubation and decreasing the need of anesthetics. 


\section{REFERÊNCIAS - REFERENCES}

1. Telci L, Esen F, Akcora D et al. Evaluation of effects of magnesium sulphate in reducing intraoperative anaesthetic requirements. $\mathrm{Br} J$ Anaesth 2002;89:594-598.

2. Bahar M, Chanimov M, Grinspun E et al. Spinal anaesthesia induced by intrathecal magnesium sulphate. Anaesthesia 1996;51:627-633.

3. Schutz-Stubner S, Wettmann G, Reyle-Hahn SM et al. Magnesium as part of balanced general anaesthesia with propofol, remifentanil and mivacurium: a double-blind, randomized prospective study in 50 patients. Eur J Anaesthesiol 2001;18:723-729.

4. Chanimoy M, Cohen ML, Grinspun $Y$ et al. Neurotoxicity after spinal anaesthesia induced by serial intrathecal injections of magnesium sulphate. An experimental study in a rat model. Anaesthesia 1997;52:223-228.

5. Alday Muñoz E, Una Orejón R, Redondo Calvo FJ et al. Magnesio en anestesia y reanimación. Rev Esp. Anestesiol Reanim 2005;52:222-234.

6. Marino PL. Magnésio. In: Marino PL. Compêndio de UTI. Porto Alegre: Artmed, 2000;529-538.

7. Nácul FE. Distúrbios eletrolíticos em medicina intensiva. In: Nácul FE. Medicina intensiva - abordagem prática. Rio de Janeiro: Revinter, 2004;309-318.

8. Roscoe A, Ahmed AB. A survey of peri-operative use of magnesium sulphate in adult cardiac surgery in the UK. Anaesthesia 2003;58: 363-365.

9. Pascarella PJ e Pineda M. Efectos del sulfato de magnesio en la respuesta hemodinamica durante la laringoscopia e intubación traqueal. Rev Venez Anestesiol 1998;3:8-12.

10. Kara H, Sahin N, Ulusan $\mathrm{V}$ et al. Magnesium infusion reduces perioperative pain. Eur J Anaesthesiol 2002;19:52-56.

11. Elsharnouby NM, Elsharnouby MM. Magnesium sulphate as a technique of hypotensive anaesthesia. $\mathrm{Br} \mathrm{J}$ Anaesth 2006;96:727-731.

12. Booth CC, Babouris N, Hanna S et al. Incidence of hypomagnesaemia in intestinal malabsorption. Br Med J 1963;2:141-144.

13. Glover ML, Machado C, Totapally BR. Magnesium sulfate administered via continuous intravenous infusion in pediatric patients with refractory wheezing. J Crit Care 2002;17:255-258.

14. Ganem EM e Castiglia YMM. Anestesia na pré-eclampsia. Rev Bras Anestesiol 2002;52:481-497.

15. McKee JA, Brewer RP, Macy GE et al. Analysis of the brain bioavailability of peripherally administered magnesium sulfate: A study in humans with acute brain injury undergoing prolonged induced hypermagnesemia. Crit Care Med 2005;33:661-666.

16. Barbosa FT, Barbosa LT, Cunha RM et al. Uso do sulfato de magnésio por via venosa e nebulização para o tratamento da asma aguda na emergência. Rev Bras Ter Intensiva 2007;19:369-373.

17. Gonçalves MM. Doença hipertensiva específica da gravidez. In: Ratton JLA. Medicina intensiva. São Paulo:Atheneu, 1997;66-76.

18. Cardoso RL, Correa CM. Pacientes obstétricos em UTI. In: Nácul FE. Medicina intensiva - abordagem prática. Rio de Janeiro: Revinter, 2004;542-548.

19. Euser AG, Cipolla MJ - Magnesium sulfate for a treatment of eclampsia: a brief review. Stroke, 2009;40:1169-1175.

20. Ramanathan J, Sibai BM, Pillai R et al. Neuromuscular transmission studies in preeclamptic women receiving magnesium sulfate. Am J Obstet Gynecol 1998;158:40-46.

21. Somjen G, Hilmy M, Stephen CR. Failure to anesthetize human subjects by intravenous administration of magnesium sulfate. J Pharmacol Exp Ther 1966;154:652-659.

22. Sibai BM, Spinnato JA, Watson DL et al. Effect of magnesium sulfate on electroencephalographic findings in preeclampsia-eclampsia. Obstet Gynecol 1984;64:261-266

23. Koontz WL, Reid KH. Effect of parenteral magnesium sulfate on penicillin-induced seizure foci in anesthetized cats. Am J Obstet Gynecol 1985;153:96-99.

24. The Eclampsia Trial Collaborative Group. Which anticonvulsant for women with eclampsia? Evidence from the collaborative eclampsia trial. Lancet 1995;345:1455-1463.

25. Karumanchi SA, Lindheimer MD. Advances in the understanding of eclampsia. Curr Hypertension Rep 2008;10:305-312.
26. Quick AM, Cipolla MJ. Pregnancy-induced up-regulation of aquaporin-4 protein in brain its role in eclampsia. FASEB J 2005;19:170-175.

27. Ghabriel MN, Thomas A, Vink R. Magnesium restores altered quaporin-4 immunoreactivity following traumatic brain injury to a pre-injury state. Acta Neurochir Suppl 2006;96:402-406.

28. Lewis DF. Magnesium sulfate: the first-line tocolytic. Obstet Gynecol Clin North Am 2005;32:485-500.

29. Wadhwa A, Sengupta $P$, Durrani $J$ et al. Magnesium sulphate only slightly reduces the shivering threshold in humans. $\mathrm{Br} \mathrm{J}$ Anaesth 2005;94:756-762.

30. Simpson JI, Eide TR, Schiff GA et al. Intrathecal magnesium sulfate protects the spinal cord from ischemic injury during thoracic aortic cross-clamping. Anesthesiology 1994;81:1493-1499.

31. Breen TW, Yang T. The changing role of magnesium sulphate therapy. Curr Opin Anaesthesiol 1999;12:283-287.

32. Dohi K, Ohtaki H, Shioda S et al. Magnesium sulfate therapy in patients with acute neuronal damage: the problem of intravenous administration. Crit Care Med 2005;33:698-699.

33. Bilotta F, Rosa G. Magnesium sulfate and neuroprotection. Anesth Analg 2003;96:1838.

34. Pivalizza EG. Magnesium sulfate and epidural anesthesia in pheochromocytoma and severe coronary artery disease. Anesth Analg 1995;81:414-416.

35. Ramirez Paesano C, Gonzalez O, Rodriguez B et al. Laringoscopia e intubación traqueal: uso de sulfato de magnesio para atenuar la respuesta cardiovascular refleja. Rev Venez Anestesiol 1998;3:66-71.

36. Stacey MR, Barclay K, Asai T et al. Effects of magnesium sulphate on suxamethonium-induced complications during rapid-sequence induction of anaesthesia. Anaesthesia 1995;50:933-936.

37. Altan A, Turgut N, Yildiz $F$ et al. Effects of magnesium sulphate and clonidine on propofol consumption, haemodynamics and postoperative recovery. Br J Anaesth 2005;94:438-441.

38. Lysakowski C, Dumont L, Czarnetzki $C$ et al. Magnesium as an adjuvant to postoperative analgesia: a systematic review of randomized trials. Anesth Analg 2007;104:1532-1539.

\section{RESUMEN}

Barbosa FT, Barbosa LT, Jucá MJ, Cunha RM - Usos del Sulfato de Magnesio en Obstetricia y en Anestesia.

JUSTIFICATIVA Y OBJETIVOS: El magnesio es un ión predominantemente intracelular. Su efecto bloqueador del receptor NMDA le confiere características analgésicas y sedativas. El objetivo de este artículo, fue revisar la fisiología, la farmacología y la disminución de la concentración plasmática del magnesio, como también de algunas de sus aplicaciones en obstetricia y en anestesia.

CONTENIDO: El magnesio es un catión intracelular que posee múltiples funciones: es cofactor de enzimas del metabolismo glicídico y de enzimas de la degradación de los ácidos nucleicos, proteínas y ácidos grasos; regula el paso de los iones transmembrana e interviene en la actividad de varias enzimas. El paciente en estado crítico, presenta una tendencia a la hipomagnesemia, y el tratamiento consiste en corregir la causa cuando es posible, acompañada de la reposición del magnesio. Ya ha quedado demostrada la reducción de la concentración alveolar mínima (CAM), de los agentes inhalatorios en animales y el uso de opioides en humanos bajo anestesia.

CONCLUSIONES: El sulfato de magnesio, ha venido siendo utilizado en obstetricia con una buena efectividad para la inhibición del parto prematuro y para el tratamiento de las crisis convulsivas asociadas al cuadro de eclampsia. Es un fármaco con potencial analgésico y sedativo que puede ser utilizado como coadyuvante durante la anestesia general, atenuando la respuesta presórica a la intubación traqueal y disminuyendo la necesidad del uso de anestésicos. 